Politics in Central Europe (ISSN: 1801-3422)

Vol. 11, No. 1

DOI: $10.1515 /$ pce-2015-0002

\title{
Employer Organisations and Business Groups in the Czech Republic
}

\author{
ANETA PINKOVÁ
}

\begin{abstract}
This article is a case study focusing on employer organisations and business organisations in the Czech Republic. In legal terms, employer organisations are a specific type of interest group with special regimes of registration and record keeping. Unlike business groups, they are endowed with certain privileges and, in particular, can participate in collective bargaining. This study analyses the relations between these two types of groups. The database originates from a questionnaire-based survey undertaken in 2010 among 91 groups representing businesses and employers. The analysis focuses on the relationship between a group's registration as an employer organisation and its orientation towards employer and business interests. It also investigates similarities between the two organisation types in terms of secondary organisation and strategies used. The analysis suggests that the differences between these two types are minimal and that the possibility of participating in collective bargaining and in tripartite counselling bodies remains the only relevant distinction. This holds true even when we take into account these groups' self-perceived primary role, i.e. defending their members as employer or as business organisations.
\end{abstract}

Keywords: Business Groups; Czech Republic; Employer Organisations; Interest Groups; Tripartite; Membership Types

\section{Introduction}

The status and character of social partners, i.e. organisations representing employers and trade unions, are among the key features determining the nature of industrial relations in any country. Compared with trade unions, employer organisations have been afforded rather marginal attention in the political sciences. Under Czech law (both before and after the new Civil Code came into force in 2014), employer organisations and trade unions - but not business

1 This text has been prepared as part of the project "Contemporary challenges of democracy in East Central Europe" (GAP408/11/0709). 
groups - are considered to be a specific type of association (for more details, see Kunc, Hartoš 2005, Vácha 2013).

This article focuses on one particular aspect of the way that employer organisations operate in the Czech Republic, namely the issue of how they relate to business groups. Both types of organisation represent essentially the same social group (entrepreneurs), but unlike employer groups, business groups may also represent businesses which do not have employees (in the Czech Republic, this mostly refers to self-employed persons; for details of business types in the Czech context, see European Commission 2011). In theory, the distinction between these types of groups is simple enough: employer organisations represent the interests of their members qua employers, particularly vis-à-vis trade unions and the government, within a framework of collective bargaining and social dialogue. Business groups represent the interests of their members in all areas except collective bargaining. Act No. 2/1991 on Collective Bargaining allows only registered employer organisations and trade unions to participate in collective bargaining. Employer organisations are endowed with some other exclusive privileges chief among which is the possibility of participating in the activities of the tripartite Council for Economic and Social Agreement (RHSD) provided that they meet other criteria such as the required membership base size (see Státu RHSD ČR 2009).

But while the distinction between the two types of organisations is clear theoretically and legally, in the practice of Czech interest group politics, the boundary is less obvious and the activities of these organisations interpenetrate: almost all employer organisations in the Czech Republic (and in most other countries) are also regularly active outside collective bargaining and social dialogue, and most business organisations are also involved in social dialogue issues. (For example, business organisations led by the Czech Chamber of Commerce were substantially involved in the drafting and parliamentary adoption of the new Labour Code in 2005-2007, and they also comment habitually on social dialogue issues; for more information on this point, see, e.g. Valterová 2007.) This article seeks to evaluate how meaningful it is to distinguish in practice between these two types of organisations whose legal status is different. The analysis is based on data obtained in a questionnaire-based survey undertaken in 2010 among 25 employer and 66 business organisations. The text draws on data presented in the monograph Employer and Business Organisations in the Czech Republic: Promoting Organized Interests (Pinkova 2011). While the data and some of the conclusions presented in this text are the same as in the original publication, the overall focus of each work is different. The original monograph, which was published in Czech and in printed form only, studies the relationship between the choice of strategy and various characteristics of each group, including its status/registration as an employer group. This article offers a deeper discussion of the differences (or, as the case may be, lack of differences) between groups 
registered as employer organisations and groups representing their members as businesspeople/businesses.

The literature available on Czech business and/or employer organisations focuses mainly on formal and legal aspects of their existence. Their positions on social dialogue and especially on issues related to collective bargaining are particularly well analysed (see, e.g. Brádel et al. 2010, Bělina 2012, Veverková 2013, Mansfeldová 2005, Hála et al. 2003). The history of the organisations is also fairly well documented (e.g. Kunc - Hartoš 2005). There is, however, surprisingly little literature on the role that these types of organisations each or both play in the political system as such, or the role they have as intermediaries between the state and society. This is probably because, unlike trade unions, business and employer groups are typically not included in studies focusing on political activism, participation and civil society (e.g. Císař - Navrátil Vráblíková 2011), which form the bulk of the current research in the field of interest intermediation. These issues were explored in the academic literature in earlier years in connection with discussions about the level (or existence) of some form of corporatism in the Czech Republic and other post-Communist countries (e.g. Ost 2000, Padgett 1999, Padgett 2000, Reutter 1996). Here, the lack of functional employer organisations able to effectively represent their members was seen as one of the main obstacles to establishing tripartism in the new democracies (see especially Padgett 2000).

\section{Background}

For the period leading up to 1989 when the Communist regime ruled what is today the Czech Republic, no relevant predecessors of employer and business organisations can be found due to the state ownership of all enterprises. Whatever the role played by earlier organisations (i.e. before 1948), the continuity between them and contemporary interest groups representing entrepreneurs and employers is chiefly symbolic. For this reason, the modern development of Czech business and employer groups began after 1989. In 1990 and even more so in 1991, professional, manufacturing and trade associations began to appear both at the level of the Czechoslovak federation and in the two republics, and while many viewed their establishment purely in terms of the renewal of activities forcefully interrupted in 1948 (see, for example, Černohorská 2003: online), this symbolic succession did not have many practical consequences (see Kroupa et al. 2004). In the early 1990 s, dozens of associations appeared representing various sectors and branches of industry. The period also saw the creation of several organisations that were more or less successful in their aim of fulfilling the role of an umbrella organisation; these included the Confederation of Industry of the Czech Republic and the Confederation of Employer and Entrepreneurs' Associations of the Czech Republic (for more information about 
their history, see, e.g. Kunc, Hartoš 2005). Whereas organisations associating emerging business interests were usually created from below, as is typical for this kind of interest group (with the obvious exception of those chambers created by law), the representation of employers' interests in the territory that is today the Czech Republic had its own somewhat specific course of development.

The tripartite Council for Social Agreement (today the RHSD) played an important role in creating organisations representing employers. At the time, its creation was mainly advocated for by new trade union elites. As there was no sufficiently representative employer organisation, the task of representing employers fell to various organisations, large companies and agricultural cooperatives (Myant - Slocock - Smith 2000: 727) which, since August 1990, had been associated through the Coordinating Council of Business Unions and Associations in the Czech Republic (KORP). Employers did not reject tripartism, but nor did they actively support it (Martin - Cristesco-Martin 1999: 394). In early 1990, they were weakly organised and lacked significant influence over economic policy (Myant - Slocock - Smith 2000: 731). One of the reasons for this was the heterogeneity of their umbrella organisation, 'combining large sectoral business unions (for example the Confederation of Industry of the Czech Republic (SP ČR) and the Association of Entrepreneurs in Building Industries), smaller businessmen associated in the Syndicate of Businesspeople of the Czech Republic, and various professional associations. The crystallisation and differentiation of interests following the economic and social transformation brought changes to the organisation. Withdrawal of the largest employers' and business' organisation SP ČR from KZPS in 1995 was a crucial step' (Kroupa et al. 2004: 21).

Whereas the $1990 \mathrm{~s}$ saw the fairly turbulent emergence, coalescence and structuring of a system of organisations representing business and employer interests (see Kroupa et al. 2004, Hála et al. 2002), since 2000, the changes in this area have only been piecemeal and the structure of these organisations can be considered fairly stable.

In the Czech Republic employerorganisations (and trade unions) are registered with the Department for Associations of the Ministry of the Interior, which maintains the relevant registry. Until 2014, the registration of social partners was regulated by Act No. 83/1990 on the Association of Citizens, and since then it has been governed by the new Civil Code and is undertaken under a special regime: employer organisations and trade unions have an advantage over other associations since their registration is not subject to the usual procedure as they are recorded in the registry simply on the basis of submitting an application. In formal and administrative terms, employer interest groups are established under Sec. 9a of Act No. 83/1990 on the Association of Citizens.

Four large employer confederations operate in the Czech Republic. "Confederation" here means an organisation which brings together collective members 
(though not to the exclusion of individual members) and is not itself a member of any other countrywide umbrella organisation. In the Czech Republic, the following organisations fulfil these criteria: the Confederation of Industry of the Czech Republic (SP ČR), the Confederation of Employer and Entrepreneur Associations of the Czech Republic (KZPS ČR), the Czech Confederation of Commerce and Tourism (SOCR ČR) and the Union of Employer Associations of the Czech Republic (UZS ČR).

In total, 61 employer organisations (as opposed to 766 trade unions) are registered in the Czech Republic (Ministerstvo vnitra [Interior Ministry] 2008). More than half of the registered organisations (31) are not included on the membership list of any confederation, and attempts to find any information about their functioning came to no avail. Of the remaining 30 organisations, 27 are associated through one of the employerconfederations or are the confederations themselves. Active employer interest groups are therefore involved to a significant degree in secondary organisations.

Of the collective members of the employer confederations, only a minority are also registered as employer organisations. The ratio is greatest for KZPS ČR whose seven members include five that are also employer organisations. In contrast, only one union member of SOCR ČR, namely the Association of Manufacturers and Importers of Flooring, is also an employer organisation. The largest employer confederation, SP ČR has 28 members of which ten are registered employer organisations. Within UZS ČR, four members are on the list of registered employer organisations.

Whereas defining employers' organisations is fairly easy since they are registered as such by the Ministry, matters are not so easy when it comes to business interest groups, which are not defined by Czech law. On the face of it, one might define business interest groups as groups associating and representing entrepreneurs in order to promote their business interests. This definition requires several clarifications, however:

An entrepreneur is a natural or legal person who is a) recorded in the business register, $b$ ) carries out business on the basis of a trade licence, $c$ ) carries out business on some basis other than a trade licence according to special regulations, or d) runs an agricultural business and is recorded in the register according to special regulations (see Act No. 513/1991, the Commercial Code). We may therefore understand that entrepreneurs' interests are those directly related to their economic activities. This rather banal clarification is needed to avoid the inclusion among business interest groups of other organisations whose members happen to be entrepreneurs (for example, leisure organisations)

As we are dealing here with a specific political and legal system, it makes sense to define what we understand by an interest group, as we did with employer organisations. Generally speaking, at the time of this research, interest groups could be defined as civic associations created under Act No. 83/1990 on 
the Association of Citizens, or as interest groups of legal persons established under Act No. 40/1964, the Civil Code. Since 2014, when the new Act No. 89/2012 Coll., the Civil Code, came into force, employerorganisations and trade unions have retained their special status while business groups formally changed have their status from "civic associations" to "associations." These definitions do not include all potential business interest groups:

The Czech Chamber of Commerce and Agricultural Chamber were established in 1992 and 1993 respectively under a special Act (No. 301/1992). According to this Act (Sec. 2 (3)), both chambers are associations of entrepreneurs (legal persons and natural persons) who have been accepted as members. As such, they are definitely organisations representing business interests, however unlike most other organisations mentioned here, they cannot be seen as voluntary and/or non-governmental associations since they are created by law and lack organisational autonomy.

Another question worth pursuing is whether professional associations ought to be considered business interest groups. Here one cannot generalise. Either each individual association has to be evaluated based on its concrete characteristics, or these associations must be seen as a specific type of organisation. Embracing the first option, we can distinguish three types of professional association. First of all, it is easy to classify those organisations which associate members according to their profession and are registered as employer organisations or trade unions. While there are about 30 registered trade unions of professionals in the Czech Republic (such as the Actors' Association and the Restorers' Trade Union), among the registered employer organisations, only the Association of Jewellers and Watchmakers of the Czech Republic can be described - with certain caveats - as professional associations (see Ministerstvo vnitra ČR [Czech Interior Ministry] 2008 for more details). Secondly, there are other organisations defined based on members' profession which defend the interests of businesses; they include some of the collective members of the Czech Chamber of Commerce, for example, the Tilers' Guild, the Drywall Installers' Guild, etc. Finally, there are professional chambers and unions associating individuals practising certain professions regardless of whether they are employees or employers.

Professional associations of the first type can be considered employer organisations since they fulfil the definition provided above. There are no objections to classifying associations of the second type as business groups since they also fulfil the relevant definition. Professional associations of the final type cannot be considered business groups as they bring together not only entrepreneurs but also employees.

The main business confederations in the Czech Republic are the Czech Chamber of Commerce (HK ČR) and the Czech Agricultural Chamber (AK ČR). Although the overwhelming majority of their members are not registered em- 
ployer organisations, they cannot be considered to be purely business groups not representing employers. Of the 72 tradespeople's associations that are members of the Czech Chamber of Commerce, six are employer organisations (of these, two are members of SP ČR and one of KZPS ČR). In total, these employer confederations bring together four and three members of HK ČR respectively. In the case of the Czech Agricultural Chamber, only one of its members, the Czech-Moravian Association of Agricultural Entrepreneurs, is a registered employer organisation and only the Agricultural Association of the Czech Republic is a member of an employer confederation (KZPS ČR). It is not registered as an employer representative, however.

\section{Results of the Research into Employers' Organisations and Business Groups}

The database on which the following analysis relies consists of the results of a questionnaire-based survey carried out among the representatives of employer and business groups in the Czech Republic during 2010. The questionnaire contained 37 questions, of which ten concerned these organisations' characteristics and three related to the relationship between groups and their members or among the groups themselves; in the remaining 24 questions, the respondents evaluated the frequency and efficiency of various strategies used (see Pinková 2011 for the full survey as well as a more detailed description of the research methodology). The respondents were asked to evaluate the activities of their groups in 2008-09. In total, 239 organisations were approached, and 91 of them submitted a completed questionnaire; the response rate, thus, stood at $38 \%$. Snowball sampling was used to identify the group or organisations approached. Because the resulting pool of respondents did not fulfil random selection criteria, the conclusions of the analysis cannot be generalised for the population at large. In statistical terms, the conclusions based on the results of the questionnaire survey are therefore only valid for the set of organisations examined. In fact, the latter constitute such a significant share of the identified population that one may assume the results' broader validity. Nonetheless, the correlation analysis, the main statistical instrument used in this work, remains at the level of descriptive statistics. Given the character of the data, which consists of categorical and ordinal variables, Spearman's correlation coefficient is used.

One of the questions posed to the respondents in the questionnaire was whether their group tends to represent its members as employers or as entrepreneurs. The answer to this question includes information extending beyond a simple distinction between organisations registered as employers and those not registered as such (though that point too was ascertained). Such registration is a one-off decision which does not necessarily indicate the present focus of the organisation: a registered organisation has the right to participate in collec- 
tive bargaining, but that does not mean that it always genuinely represents its members in negotiations with trade unions. The respondents were, thus, asked to evaluate the real focus of their organisations. The distribution of answers to the first question is displayed in Figure 1.

\section{Figure 1: Distribution of groups according to their representation of employers vs. businesses}

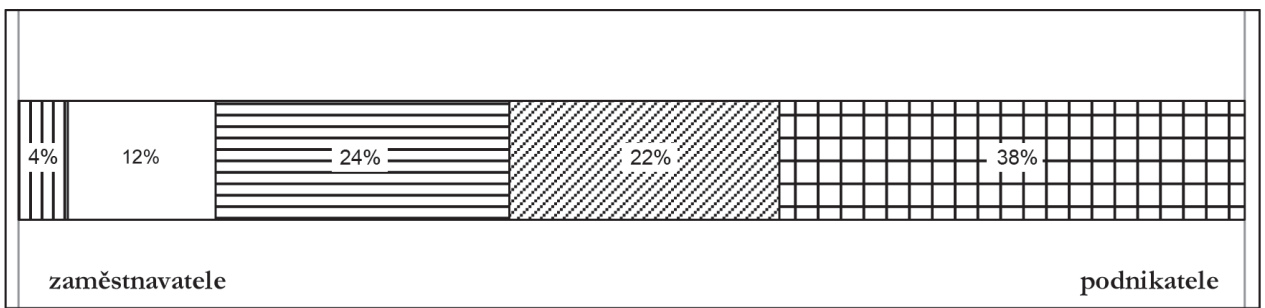

$\mathrm{N}=91$. Own figures, data source: questionnaire survey "Organisations representing employers and businesses."

Of the 91 organisations examined, 25 (i.e. 27\%) are registered with the Ministry of the Interior as employer organisations and the remaining 66 groups do not have the status of employer organisations under Act No. 83/1990 on the Association of Citizens. The results of the survey nevertheless suggest that registration itself is not the decisive factor in determining an organisation's self-perception about whether it represents employers or businesses. Of the 25 registered employer organisations the largest number (nine, 36\%) said that they represent their members as employers and businesses to the same degree. Surprisingly, the second largest group of registered employers said that they represent their members primarily as businesses; only seven groups understood themselves as representing their members more as employers than as businesses (five, 20\%) or exclusively as employers (two, $8 \%$ ).

In contrast, groups not registered as employers had established fairly clear profiles as organisations representing businesses ( 45 groups, $68 \%$ ). The largest share of these groups said that they represent their members purely ( 28 groups, $42 \%$ ) or mostly (17 groups, $26 \%$ ) as businesses. If we look at the organisations examined as a whole, we find that the majority (38\%) represent their members primarily as businesses, while the second largest group (24\%) represent them as employers and businesses to the same degree. Only around $4 \%$ of organisations indicated that they represent their members solely as employers. Table 1 summarises the distribution of answers between (registered) employer and business organisations. 
Table 1: Distribution of answers between (registered) employer and business organisations

\begin{tabular}{|l|c|c|c|}
\hline Members are represented & EMPLOYER & BUSINESS & Total \\
\hline As employers & 2 & 2 & 4 \\
\hline More as employers than as businesses & 5 & 6 & 11 \\
\hline As employers and businesses to the same degree & 9 & 13 & 22 \\
\hline More as businesses than as employers & 3 & 17 & 20 \\
\hline As businesses & 6 & 28 & 34 \\
\hline Total & 25 & 66 & 91 \\
\hline
\end{tabular}

$\mathrm{N}=$ 91. Own table, data source: questionnaire survey “Organisations representing employers and businesses." EMP - Groups registered as employer orgs., BUSINESS - Business groups not registered as employer orgs.

If we calculate the correlation between the two variables (i.e. formal registration as an employer organisation, and self-perception about representing businesses or employers), we find an almost moderate correlation (.261). Organisations registered as employers were therefore more likely to say that they represent their members more as employers than as businesses. That there was some correlation here is not surprising; what is surprising is that it was so weak. For most organisations, general business interests took precedence over the specific role of their members qua employers or as one of the parties in the social dialogue. It is also obvious that employers' interests and the representation of employers do not consist solely of collective bargaining, but involve a broader defence of employers' interests (for instance, consultations about labour legislation): otherwise, the defence of these interests would have to be linked exclusively to registration as an employer organisation. However, this wider understanding was confirmed.

The question of how the two variables that allow us to distinguish between employer and business organisations correlate with other characteristics of interest groups is answered in Table 2. Here, the variables "registration as an employer organisation" and "representation of employer vs. business interests"' are correlated with the variables "budget" and "type of membership" (where options include purely individual, collective and both collective and individual). 
Table 2: Correlations between selected variables

\begin{tabular}{|c|c|c|c|c|c|c|}
\hline & BT & REG & REP & IND & I/C & COL \\
\hline BT & 1 & 0.390 & 0.107 & 0.072 & 0.080 & 0.017 \\
\hline REG & 0.390 & 1 & 0.269 & 0.077 & 0.051 & 0.052 \\
\hline REP & 0.107 & 0.269 & 1 & 0.157 & 0.026 & 0.267 \\
\hline IND & 0.072 & 0.077 & 0.157 & 1 & 0.879 & 0.249 \\
\hline I/C & 0.080 & 0.51 & 0.026 & 0.879 & 1 & 0.242 \\
\hline COL & 0.017 & 0.052 & 0.267 & 0.249 & 0.242 & 1 \\
\hline
\end{tabular}

Spearman's rho, listwise $\mathrm{N}=78$. Own table, data source: questionnaire survey “Organisations representing employers and businesses." BT - budget; REG - Registration as an employer organisation; REP - Representation of employer vs. business interests; IND - Individual membership; I/C - Individual and collective membership; COL - Collective membership

Clearly, the (expected) type of membership does not play a role in the key decision that an emerging interest group has to make, namely whether or not to register as an employer organisation. A certain correlation does appear, however, which we might consider interesting in the social science context: this is the one between registration as an employer organisation and budget. As the budget increases, so too does the chance that the organisation is registered as an employer. In other words, organisations with larger budgets tend to register themselves as employer organisations, or interest groups registered as employer organisations tend to have a larger budget at their disposal.

Let us now look more closely at the differences between strategies chosen by employer and business groups. Table 3 summarises the correlations between the variable "registration as an employer organisation" and the frequency with which the various strategies were used.

Table 3: Overview of correlations between a group's registration as an employer organisation and the absolute frequency of its employment of the various strategies

\begin{tabular}{|c|c|c|c|c|c|c|}
\hline & P-P & P-A & ON & UNO & FC & IC \\
\hline REG & 0.284 & 0.341 & 0.373 & 0.195 & 0.150 & 0.246 \\
\hline & PR & PRM & INT & LEG & PRES & MED \\
\hline REG & 0.352 & 0.154 & 0.123 & 0.165 & 0.064 & 0.388 \\
\hline
\end{tabular}

Spearman's rho, listwise, $N=79$. Own table, data source: questionnaire survey "Organisations representing employers and businesses." REG - Registration as an employer organisation; P-P - Participation in parliamentary sessions and committees; P-A - Participation in advisory bodies - government or ministries; ON - Official negotiations with politicians and senior civil servants; UNO - Unofficial negotiations with politicians and senior civil servants; FC - Formal commenting on draft bills; IC - Informal commenting on draft bills, PR - Press conferences; PRM - Promotion of the group offline; INT - Publication of information online; LEG - Legal strategies; PRES - Pressuring strategies; MED - Media appearances 
In only one case (pressure strategies) was there no correlation between the frequency with which a strategy was employed and the organisation's registration. In five other cases, the correlation was weak; for half of the strategies, however, there was a moderate correlation. Stronger correlations appeared regardless of whether the focus was insider/outsider or formal/informal strategies: employer organisations tend to appear in the media and to organise press conferences more often, which may be related to their specific role as actors in collective bargaining. Their more frequent participation in meetings of parliamentary committees and advisory bodies as well as in official negotiations with politicians and senior civil servants and as informal commenters on draft bills might also be linked with the social dialogue, or with the higher degree of institutional incorporation of employer groups, which has been mentioned above. In no case was the correlation coefficient high enough to interpret the correlation as substantial.

Budget size, which was fairly strongly correlated with registration as an employer group (.407), might also play a role. In other words, groups with more substantial yearly budgets are more often registered as employer organisations. Groups with larger budgets then have the means to be more active, which might indirectly influence the correlation between registration as an employer group and the frequency with which strategies are employed. For this reason, the correlations were re-calculated, this time as partial correlations, excluding the influence of budget size. The results are summarised in Table 4.

\section{Table 4: Overview of correlations between a group's registration as an employer organisation and the overall frequency of its use of various strategies}

\begin{tabular}{|c|c|c|c|c|c|c|}
\hline & P-P & P-A & ON & UNO & FC & IC \\
\hline REG & 0.255 & 0.155 & 0.273 & 0.073 & 0.160 & 0.201 \\
\hline & PR & PRM & INT & LEG & PRES & MED \\
\hline REG & 0.173 & 0.193 & 0.002 & 0.174 & 0.083 & 0.206 \\
\hline
\end{tabular}

Partial correlation, listwise, $\mathrm{N}=79$. Own table, data source: questionnaire survey “Organisations representing employers and businesses." REG - Registration as an employer organisation; P-P - Participation in parliamentary sessions and committees; P-A - Participation in advisory bodies - government or ministries; ON - Official negotiations with politicians and senior civil servants; UNO - Unofficial negotiations with politicians and senior civil servants; FC - Formal commenting on draft bills; IC Informal commenting on draft bills, PR - Press conferences; PRM - Promotion of the group offline; INT - Publishing of information online; LEG - Legal strategies; PRES - Pressuring strategies; MED - Media appearances.

In comparison with the original coefficients, some partial coefficients decreased fairly substantially. The only case where budget size did not play a significant role was in connection with participation in parliamentary committee sessions. In the case of three strategies (unofficial negotiations with politicians and sen- 
ior civil servants, publishing of information online and pressuring strategies), the original correlation disappeared entirely and was obviously only a false correlation linked to the group's budget size. For the remaining strategies, it is true that a correlation remained apparent, but for the most part, it was lower than seen for the original coefficients. Although differences existed between employer and business groups in terms of selecting strategies, these were not great and were at least partially the corollary of the larger budgets that employer organisations have at their disposal.

\section{Discussion and conclusion}

The results of the questionnaire-based survey show that groups registered as employers certainly cannot be considered to be organisations focusing solely on defending employers' interests. Similarly, organisations that are not registered as employers also substantially defend interests of their members that are linked with their positions as employers. An explanation for these facts can be sought on multiple levels:

The defence of employer and business interests cannot be entirely separated in practice because the conditions under which a company or a self-employed individual engages workers inevitably influence their business interests. Even groups that focus primarily on the social dialogue might view their activities as being in the defence of business interests and choose their answers accordingly. By the same logic, business organisations which do not directly intervene inthe social dialogue defend the interests of their members qua employers: a typical example of this is the already mentioned involvement of the Chamber of Commerce in negotiating the Labour Code (see Valterová 2008 for more details). We can therefore assume that this is the reason why some organisations claim to defend employers' interests even though they do not participate in collective bargaining in any way, and vice versa.

On top of this, the law does not stipulate any special criteria for the registration of employerorganisations. It is therefore quite possible that a number of organisations registered in the early $1990 \mathrm{~s}$ or later as employer organisations (notably this is an area where the registration procedure is also simpler), but in later years their activities went in a different direction. This means that in addition to functioning organisations which do not participate in collective bargaining, the list also includes many groups which no longer exist or are inactive. As registration does not bring any obligations or disadvantages, groups which do not really represent their members in collective bargaining have no reason to change their registration.

A casual glance at the membership structure of the main umbrella organisations in this area suggests that registration as an employer organisation is not decisive when it comes to establishing cooperative relations among the groups: 
umbrella organisations registered as employers count many business groups among their members, and vice versa. Similarly, comparing the answers to the two questions concerning the division into employer and business organisations suggests that registration is not decisive for interest group orientation. A significant share of interest groups registered as employer organisations represent their members primarily as businesses, and a few of the non-registered groups examined represent their members more or even primarily as employers. This does not mean that there is no correlation between the variables "registration as an employer group" and "representation of employer vs. business interests," however given the nature of the variables, the correlation level is surprisingly low (0.390). Outside the specific area of collective bargaining, it seems therefore that the matter of registration as an employer organisation does not determine the focus of the interest group.

The results of the analysis also suggest a weak correlation between the frequency of employing most of the strategies observed and the (non-)registration of an organisation as an employer. This difference is substantially due to the fact that larger groups more often tend to be registered as employer organisations. In the analysis presented here, group size was represented by the "budget size" variable. If the correlation is stripped of the influence exerted by budget size, small differences between employer and business groups remain; in practice, however, the two types of organisations do not diverge significantly in how they promote their interests vis-à-vis the bureaucratic and political elite.

Another area in which differences between employer associations and other business organisations might be detected concerns the formal channels offered by the political system for influencing the political process. As one side in tripartite negotiations, employer associations are in a more advantageous position in this sense. Employer associations which fulfil the so-called representativeness criteria may become members of the RHSD. Although the conclusions reached by this Council and the documents negotiated therein are not legally binding and the Council only has an advisory role (unlike its members, itis not mandatorily consulted in the law-making process), these tripartite negotiations are important because they allow social partners to present their views, obtain information from their counterparts and promote their interests. Nevertheless, given the way that the representativeness criteria are set up, the chance to take part in tripartite negotiations at national level is only open to the largest organisations; from among the employers, this means SP ČR, KZPS ČR and the Czech Confederation of Commerce and Tourism, the last through SP ČR.

On the whole, it can be said that in practice the differences between employer and business organisations appear chiefly in connection with collective bargaining, which business groups can only enter into indirectly based on their membership of an employer umbrella organisation. At the same time, 
a non-negligible number of employer organisations do not participate in collective bargaining at all; they represent their members solely as businesses and not as employers. In other areas, the differences between the two types of organisation are minimal, and in certain respects (membership of secondary organisations, for example), they fade away entirely. The research shows that in the Czech Republic, it only makes sense to distinguish between business and employer organisation if one focuses on the issues of collective bargaining or on the activities of large umbrella organisations which are represented in the Council for Economic and Social Agreement. An employer organisation may be understood most fruitfully as a subtype of business organisation, i.e. as a business interest group that is registered as an employer organisation. This conclusion partially questions the meaningfulness of the traditional Czech dichotomy between employer organisations and trade unions. The defence of employers' interests is much wider than collective bargaining and includes issues such as lobbying for changes in labour law legislation. The results of the questionnaire survey presented in this article demonstrate that many business groups represent (or see themselves as representing) their members as employers even though they are not allowed to participate in collective bargaining (or in negotiations of the tripartite RHSD). Bearing this in mind, a dichotomy between business groups and trade unions makes more sense in the Czech context than the more often used one between employer groups and trade unions.

\section{References}

Bělina, Miroslav a kol. (2012): Pracovní právo. 5. dopl. a podstat. přeprac. vyd. Praha: C.H. Beck. Brádel, Jan - Brádlerová, Libuše - Filip, Stanislav - Hejduková, Jitka - Klimeš, Stanislav - Šubrt, Bořivoj (2010): Analýza kolektivního vyjednávání. Praha: Svaz půrmyslu a dopravy. Available at: http://www.socialnidialog.cz/images/stories/Analyzy/Analyza_Kolektivni_vyjednavani. pdf (25 May 2015).

Cisař, Ondřej - Navrátil, Jiř̌́ - Vráblíková, Kateřina (2011): Staří, noví, radikální: politický aktivismus v České republice očima teorie sociálních hnutí. Sociologický časopis / Czech Sociological Review 47 (1). Available at: http://sreview.soc.cas.cz/uploads/4cd36bfb874e0b1d09cb08912c 7224b2c3e7b687_CisarNavratilVrablikovaSC\%201-2011.pdf (May 252015).

Černohorská, Marie (2003): Vznik Českého svazu pivovarů a sladoven a historie Spolku pro průmysl pivovarský. Available at http://www.pivnidenik.cz/clanek/457-Vznik-Ceskeho-svazu-pivovaru-a-sladoven-a-historie-Spolku-pro-prumysl-pivovarsky/index.htm (18 June 2013).

European Commission (2011): Business Environment. Annex 1 C Czech Republic. Available at: http://ec.europa.eu/enterprise/policies/sme/business-environment/files/annexes_accounting_report_2011/czech_republic_en.pdf (27 MAY 2015) 
Hála, Jaroslav - Kroupa, Aleš, Mansfeldová, Zdenka - Kux, Jaroslav - Vašková, Renáta - Pleskot, Igor (2002): Rozvoj sociálního dialogu v ČR. Praha: VÚPSV.

Hála, Jaroslav - Kroupa, Aleš - Kux, Jaroslav - Mansfeldová, Zdenka - Rakušanová, Petra (2003): Social Dialogue and EMU in the Candidate Countries? The Czech Republic, Social dialogue and $E M U$ in the acceding countries, Dublin: European Foundation for the Improvement of Living and Working Conditions.

Kroupa, Aleš - Hála, Jaroslav - Vašková, Renata - Mansfeldová, Zdena, Šimoník, Pavel (2004): Odbory, zaměstnavatelé, sociální partneři - odborová organizovanost v ČR a hlavní faktory jejího vývoje. Praha: VúPSV.

Kunc, Stanislav, Hartoš (2005): Zaměstnavatelské svazy - Svaz průmyslu a dopravy ČR a Konfederace zaměstnavatelských a podnikatelských svazů ČR, in Mansfeldová, Zdenka - Kroupa, Daniel, eds., Participace a zájmové skupiny v České republice, 159 - 183, Praha, SLON.

Martin, Roderick - Cristeco-Martin, Anamaria (1999): Industril relations in transformation: Central and Eastern Europe in 1998. Industrial Relations Journal 30 (4): 387-404.

Mansfeldová, Zdenka (2005): Sociální dialog a jeho budoucnost, in Mansfeldová, Zdenka Kroupa, Aleš, eds., Participace a zájmové organizace v České republice, 105-128, Praha: Sociologické nakladatelství SLON.

Ministerstvo vnitra ČR (2008): Seznam odborových a zaměstnavatelských organizací k červnu 2008, unpublished document.

Myant, Martin - Slocock, Brian - Smith, Simon (2000): Tripartism in the Czech and Slovak Republics. Europe-Asia Studies 52 (4): 723-739.

Ost, David (2000): Illusory Corporatism in Eastern Europe: Neoliberal Tripartism and Postcommunist Class Identities, Politics \& Society 28 (4): 503-530.

Padgett, Stephen (1999): Tripartism Without Corporatism: Organized Interests the State and Public Policy in Postcommunist Eastern Germany, unpublished paper, European Consortium for Political Research, Mannheim.

Padgett, Stephen (2000): Organizing Democracy in Eastern Germany; Interest Groups in Post-Communist Society, Cambridge: Cambridge University Press.

Pinková, Aneta (2011): Zaměstnavatelské a podnikatelské organizace v ČR: Prosazování organizovaných zájmů, Brno: CDK.

Reutter, Werner (1996). Tripartism without Corporatism: Trade Unions in Central and Eastern Europe, in Aght, Attila. - Ilonszki, Gabriella, eds., Parliaments and Organised Interests: The Second Steps, 59-78, Budapest: Hungarian Centre for Democracy Studies.

Statut RHSD ČR (2009) Available at: http://www.mpsv.cz/cs/6437 (8 July 2015).

Valterová, Aneta (2007): Manifestation of Corporatism in the Czech Republic, Pisa: $4^{\text {th }}$ ECPR General Conference, available at: http://ispo.fss.muni.cz/uploads/2download/Working_papers/ispo_wp_2007_3.pdf (8 July 2015).

Vácha, Jan (2013): Odborové organizace v područí právní úpravy v novém občanském zákoníku, Pracovní právo 2013, Masarykova univerzita, available at: https://www.law.muni.cz/sborniky/ pracpravo2013/files/010.html (8 July 2015) 
Veverková, Soňa (2013): Czech Republic - Labour Relations and Social Dialogue, Annual Review 2013, Warsaw, Friedrich Ebert Stiftung. Available at: http://library.fes.de/pdf-files/bueros/ warschau/10435.pdf (8 July 2015).

European Commission 2011 Available at: http://ec.europa.eu/enterprise/policies/sme/business-environment/files/annexes_accounting_report_2011/czech_republic_en.pdf (8 July 2015).

\section{Other sources}

Act No. 2/1991 Coll, on Collective Bargaining.

Act No. 40/1964 Coll., the Civil Code.

Act No. 83/1990 on the Association of Citizens.

Act No. 89/2012 Coll., the Civil Code.

Act No. 301/1992 Coll., on the Czech Chamber of Commerce and the Agricultural Chamber of the Czech Republic.

Act No. 513/1991 Coll., the Commercial Code.

Aneta Pinková works at the Department of Political Science, Faculty of Social Studies, Jostova 10, Brno 602 00, Czech Republic. Katedra politologie, Fakulta sociálních studií.E-mail:valterov@fss.muni.cz 